\title{
Trees to towers shift: Power lines emerging as a novel habitat for birds in Gujranwala, Pakistan
}

\author{
Zunaira Noreen ${ }^{1 *}$ and Khawar Sultan ${ }^{1}$ \\ 1. Department of Environmental Sciences, University of Lahore, Defence Road Campus, Lahore, Pakistan \\ Corresponding author's email: zunaira.norin@gmail.com \\ Citation \\ Zunaira Noreen and Khawar Sultan. Trees to towers shift: Power lines emerging as a novel habitat for birds in \\ Gujranwala, Pakistan. Pure and Applied Biology. Vol. 11, Issue 2, pp616-628. \\ http://dx.doi.org/10.19045/bspab.2022.110063
}

Received: 15/06/2021 Revised: 26/08/2021

Accepted: 03/09/2021

Online First: 18/09/2021

\section{Abstract}

Power infrastructure (electricity towers, mobile phone towers, transmission lines and wires) is a unique anthropogenic structure in terms of material composition, design and continuity serving as artificial habitat to avian wildlife for roosting and nesting. This study aimed at finding out the diversity, abundance and behaviour of birds using the power structures as artificial habitat in the Gujranwala city area, Pakistan. Field data was collected in Feb-Mar 2021 during the COVID-19 pandemic and resulting lockdowns in the city by recording all birds' species and nests on power lines along a circular path $(\sim 32 \mathrm{~km})$ by dividing into sampling zones. A total of 24 bird species of 16 families were found to be using these structures as roosting and nesting sites. The occupation rate of mobile phone towers is found to be $61 \%$, transmission lines $32 \%$, and electricity towers $1.8 \%$. House crow was the most common species ( $20 \%$ population) followed by the Black kite ( $\sim 18 \%$ population). The spatial distribution pattern of nests on power structures indicated higher concentration in the southwestern area contrary to the highest abundance and diversity in the northwestern area close the urban forest planation. Total 112 nests of 4 species (Black kite, House crow, Common myna and Eurasian collard dove) were present on power lines. Black kite is the most frequent nesting species ( $>80 \%$ of all nests), preferring high structures i.e. transmission lines (99\% of all nests) and mobile phone towers (78\% of all nests) for making nests. House crow and Common myna make nests on electricity towers at low height. It is found that the area where cutting of trees during the past time period occurred, birds have shifted their nesting habitat from trees to towers (i.e., power structures). Moreover, if habitat destruction continues these power lines will be the new nesting habitat of the birds in the urban area, hence, posing risks to both birds and utility structures. This study also highlighted the importance of strategic plantation in relation to spatial distribution and protection of urban birds.

Keywords: Birds; COVID-19 lockdowns; Diversity; Phone towers; Power lines; Urbanization

\section{Introduction}

The urbanized structures such as buildings, roads, bridges, power supply lines, and mobile phone towers are rapidly replacing the natural structures like forests, agricultural lands, and wetlands with each passing day. These structures are sometimes beneficial for the wild life (e.g. birds, mammals) by providing the places for shelter, roosting and breeding [1]. On the other hand, these 
structures can be harmful by increasing the collusions of wild life and interaction with harmful materials in urban environment [1, 2]. The development of power structures (i.e., electricity towers, poles, mobile phone towers, transmission towers and wires) has made their excessive use by bird species for roosting, perching and nesting in cities $[3,4]$. The power lines are spread worldwide [5] and is a unique anthropogenic structure that is consistent in its material composition and design in different regions of the world. Many bird species including several species of conservation concern like e.g., vultures, eagles, storks, are reported to have been using the power lines as habitat and nesting places $[3,4]$. While these power lines provide important nesting substrate to these bird species, they also make bird species more vulnerable to injuries and deaths by direct collision and electrocution [6], hence, threatening long-term survival of the species [7]. The economic losses have also been reported because of power outages and failure of electricity supply by electrocution and touching of nesting material [8,9]. Pakistan with rather higher rate of urbanization in the South Asian countries, with $36.4 \%$ of its population living in cities [10], is developing and expanding urban structures such as bridges, buildings and power supply lines even in rural areas of the country. Gujranwala is such big city and is one of the most important industrial hubs of Pakistan. This study is conducted in Gujranwala city area to find out whether these power lines (electricity towers, mobile phone towers, wires and poles) are being used as habitat both as roosting and nesting by wild avian species and the possible role of wires in sustaining bird's population. Moreover, this study will also find the most suitable structures that are being used as habitat.

\section{Materials and Methods Study area}

The study was conducted in the Gujranwala city, the seventh most populous metropolitan ( $\sim 5$ million people) in Pakistan located in the northeast of Punjab Province [11]. It has semi- humid climate type with temperature ranging from $7{ }^{\circ} \mathrm{C}$ to $42{ }^{\circ} \mathrm{C}$ between winter and summer $[12,13]$. The annual amount of precipitation in Gujranwala is $581 \mathrm{~mm}$. All area inside the city, marked by circular line in (Fig. 1), is urbanized as compared to the outside of circle, which has more rural-urban setting. The landscape changes in character along the road (and power lines) with, dense housing, markets, vacant lots, graver yards, schools, hospitals, etc. In the eastern side of city, a Canal Bank Forest is also present on the $8 \mathrm{~km}$ road stretch. Agricultural fields are present all along the western side of road up until the Pindi bypass and then the urban area starts again.

\section{Field data collection}

The field data was collected in FebruaryMarch 2021 in spring season with a mild temperature ranges from $4{ }^{\circ} \mathrm{C}$ to $30{ }^{\circ} \mathrm{C}$. The sampling was carried out in the clear and sunny days during the periods of partial lockdowns of COVID-19 (coronavirus disease of 2019). The field data of birds' abundance, diversity and behavior was collected by walking on the roads and on vehicle around the central city area along the power lines of about $32 \mathrm{~km}$ in length. The whole study area was divided into fourteen zones (Fig. 1) for better characterization. Each zone was sampled thrice in the study period. Data was collected between 8 am and 10 am in the morning, a time of peak activity of birds. The sampling started from Sialkot bypass at the northern end (Zone 1) and continued towards the south end at the Chan da Qila Chowk and passing from Khiali and Pindi bypasses ended at Sialkot bypass again (Zone 14). In this way, a complete circle stretching about $32 \mathrm{~km}$ in length was 
completed as shown in (Fig. 1). Every type of tower, i.e. electricity tower (steel, concrete), mobile phone tower, and the continuous transmission lines were covered in this sampling. The exact number and type of birds using these structures were counted. The number of nests present on the structures was also counted. Three factors were considered while studying the nests on the structures, i.e., the structural design, surrounding, material type of towers, and the availability of place for the nests. The binocular was used to identify species sitting high on electricity tower and mobile phone towers. The photographs were also taken to identify species. Avian species were identified with help of field manuals $[14,15]$.

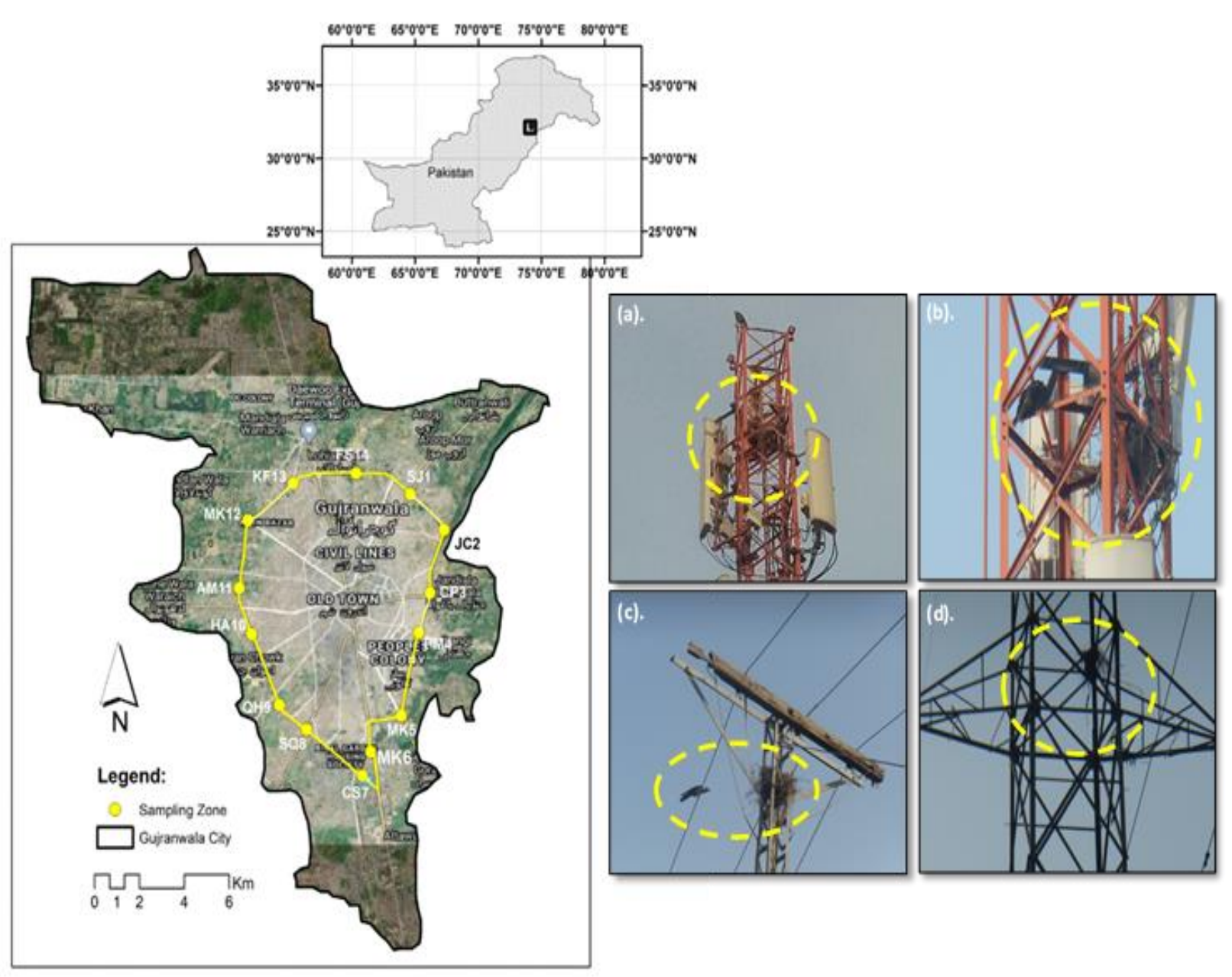

Figure 1. Map showing locations of 14 sampling zones in the Gujranwala city. Mobile phone tower (a \& b), transmission line (c) and electricity tower (d) and are being used by local avifauna, as an alternative habitat due to absence of tall trees in the urban area

\section{Statistical analysis}

SPSS and MINITAB were used to analyze the data. The relative abundance of each species in the population was determined by the formula as $(\mathrm{Pi}) \mathrm{Pi}=\mathrm{Ni} / \mathrm{N}$. Fowler and Cohen [16] methodology was used for
Statistical analysis. Avian species diversity index in each zone was calculated by Shannon and Weaver diversity index [17]. Species Richness (SR) [18] and Species Evenness (E) was also calculated for avifauna of the area [19]. Principal 
Component Analysis (PCA) was carried out to find out the correction among variables and group behavior of avian species. Geographic information system (GIS) and Google imagery were used to develop the spatial distribution maps of the field data.

\section{Results}

\section{Avian species on power lines}

A total of 2623 birds of 24 species belonging to 16 avian families were found to be using the electricity towers, mobile phone towers, transmission lines and wires as roosting and nesting sites along $32 \mathrm{~km}$ distance of the city area. The Columbidae and Hirundinidae are most diverse families having 4 species each but the Corvidae and Accipitridae are the most abundant families making $38 \%$ of population collectively. House crow was the most common species making $19.8 \%$ of population followed by Black kite making $17.7 \%$ of the population. House sparrow and Common myna are next abundant species making $17.04 \%$ and $14.33 \%$ species populations, respectively. Rock dove also made a significant contribution to population $(6.44 \%)$. The (Table 1$)$ is shows the type of species and their percentages of population.

Table 1. Bird families, species, residential status, found on electricity wires and towers

\begin{tabular}{|c|c|c|c|c|c|}
\hline $\begin{array}{c}\text { S. } \\
\text { No. }\end{array}$ & $\begin{array}{c}\text { Species common } \\
\text { Name }\end{array}$ & Scientific name & Family Name & Status & $\begin{array}{c}\text { Percent } \\
\text { Population }\end{array}$ \\
\hline 1 & House crow & Corvus splendens & Corvidae & Resident & $19.79 \%$ \\
\hline 2 & Brown rock chat & Cercomela fusca. & Muscicapidae & Resident & $0.15 \%$ \\
\hline 3 & Wire-tailed swallow & Hirundo smithii & Hirundinidae & Resident & $0.80 \%$ \\
\hline 4 & Barn swallow & Hirundo rustica & & Resident & $2.25 \%$ \\
\hline 5 & Grey- throated martin & Riparia chinensis & & Resident & $3.93 \%$ \\
\hline 6 & $\begin{array}{c}\text { Common house } \\
\text { martin }\end{array}$ & Delichon urbicum & & Winter migrant & $2.52 \%$ \\
\hline 7 & Rock dove & Columba livia & Columbidae & Resident & $6.44 \%$ \\
\hline 8 & Red collared dove & $\begin{array}{c}\text { Streptopelia } \\
\text { tranquebarica }\end{array}$ & & Resident & $0.95 \%$ \\
\hline 9 & Eurasian collard dove & Streptopelia decaocto & & Resident & $0.72 \%$ \\
\hline 10 & Laughing dove & Spilopelia senegalensis & & Resident & $0.88 \%$ \\
\hline 11 & White-throated & Halcyon smyrnensis & Alcedinidae & Resident & $0.46 \%$ \\
\hline 12 & Pied kingfisher & Ceryle rudis & & Resident & $0.15 \%$ \\
\hline 13 & Red-vented bulbul & Pycnonotus cafer & Pycnonotidae & Resident & $2.86 \%$ \\
\hline 14 & Bank myna & Acridotheres ginginianus & Sturnidae & Resident & $1.87 \%$ \\
\hline 15 & Common myna & Acridotheres tristis & & Resident & $14.33 \%$ \\
\hline 16 & Indian Pond heron & Ardeola grayii & Ardeidae & Resident & $0.88 \%$ \\
\hline 17 & Black drongo & Dicrurus macrocercus & Dicruridae & Resident & $3.01 \%$ \\
\hline 18 & House sparrow & Passer domesticus & Passeridae & Resident & $17.04 \%$ \\
\hline 19 & Isabelline shrike & Lanius isbellinus & Laniidae & Winter migrant & $0.08 \%$ \\
\hline 20 & House swift & Apus nipalensis & Apodidae & Resident & $2.55 \%$ \\
\hline 21 & Black kite & Milvus migrans & Accipitridae & Resident & $17.69 \%$ \\
\hline 22 & Green bee-eater & Merops orientalis & Meropidae & Resident & $0.46 \%$ \\
\hline 23 & Purple sunbird & Cinnyris asiaticus & Nectariniidae & Resident & $0.11 \%$ \\
\hline 24 & Plain prinia & Prinia inornata & Cisticolidae & Resident & $0.08 \%$ \\
\hline
\end{tabular}


Distribution of species in zones

About $32 \mathrm{~km}$ long wires, 1636 electricity towers of six types (based on materials such as concrete, steel and design), 128 mobile phone towers and 27 transmission lines were surveyed in all 14 zones around the city. Zone 2 and 6 were found to be the richest in abundance ( $N=875,400$, respectively) and most diverse with diversity index of $\left(H^{\prime}=2.924\right)$ and $\left(H^{\prime}=2.479\right)$. The zone 14 was found to be the lowest in abundance and diversity, $\quad(N=72)$ and $\quad\left(H^{\prime}=1.213\right)$, respectively. Statistically, no significant correlation was observed between number of towers in a zone (U_ 0.3 ; PB 0.5 Mann_Whitney U-test) and abundance and diversity of birds (x2_ 1.94, PB 0.01 with Yate's correction) because the zones which recorded the highest number of towers were not richest in the abundance and diversity of birds. For instance, the zone 2 having only 73 towers is found to be the richest in avian diversity $\quad\left(\mathrm{H}^{\prime}=2.924\right)$ and abundance $(N=875)$ while zone 5 which has highest number of towers (192) reported only 114 birds and diversity index of $\left(H^{\prime}=2.379\right)$.
Avian species using power lines as nesting sites

A total of 1636 electricity towers, 27 transmission lines and 128 mobile phone towers were sampled in this study. Total 112 nests of four species were present on these power lines. From the six types of electricity towers in design and material nests were present only on steel towers having zig zag design (Fig.1(c)) and the occupation rate of these electricity towers was $1.8 \%$. The 27 nests of three avian species (House crow and Common myna, Eurasian collard dove) were present on electricity towers. At the 27 transmission lines, 9 nests of only one avian species (Black kite) and one unknown nest was present. The occupation rate of transmission line was $32 \%$. From sampled 128 mobile phone towers nests were present on $79 \%$ towers and it recorded the highest occupation rate of $61 \%$. The nests of three avian species were present on these towers. The $79 \%$ of these nests were of Black kite. The $12 \%$ of nests were of House crow and $7 \%$ of Common myna. The $2 \%$ nests could not be identified because no bird was present at the time field sampling. The (Table 2) shows the type of towers and nesting species on them.

Table 2. Type of electricity structure, occupation rate and nesting species

\begin{tabular}{|c|c|c|c|c|c|c|}
\hline $\begin{array}{l}\text { S. } \\
\text { No. }\end{array}$ & $\begin{array}{c}\text { Type of } \\
\text { electricity } \\
\text { structure }\end{array}$ & Number & $\begin{array}{l}\text { Total } \\
\text { Nests }\end{array}$ & $\begin{array}{l}\text { Occupation } \\
\text { rate }\end{array}$ & Nesting species & $\begin{array}{l}\text { Percentage of } \\
\text { nesting species }\end{array}$ \\
\hline 1 & $\begin{array}{l}\text { Electricity } \\
\text { Towers }\end{array}$ & 1636 & 27 & $1.80 \%$ & $\begin{array}{c}\text { House crow } \\
\text { Common myna } \\
\text { Eurasian collard dove } \\
\text { Unknown }\end{array}$ & $\begin{array}{c}70 \% \\
29 \% \\
3 \% \\
8 \% \\
\end{array}$ \\
\hline 2 & $\begin{array}{c}\text { Transmission } \\
\text { lines }\end{array}$ & 27 & 9 & $32 \%$ & $\begin{array}{l}\text { Black kite } \\
\text { Unknown }\end{array}$ & $\begin{array}{c}99 \% \\
1 \%\end{array}$ \\
\hline 3 & $\begin{array}{c}\text { Mobile phone } \\
\text { Towers }\end{array}$ & 128 & 79 & $61 \%$ & $\begin{array}{c}\text { Black kite } \\
\text { House crow } \\
\text { Common myna } \\
\text { Unknown }\end{array}$ & $\begin{array}{c}79 \% \\
12 \% \\
07 \% \\
2 \% \\
\end{array}$ \\
\hline
\end{tabular}




\section{Presence of nests in relation to structures}

Out of six types of electricity towers only one type of tower is favored as nesting sites (Fig.1(c)). All nests of three species (House crow, Common myna, and Eurasian collard dove) were present on this type of tower. The height of tower was $12 \mathrm{~m}$ and its design is similar to mobile phone tower (zig zag) but height is half to the tower. Not a single nest was found on any other type of electricity tower regardless of material composition such as steel, concrete, cement, etc. On the mobile phone tower three species Black kite, House crow, Common myna, Unknown were found to be making nests. The Black kite made the nest on top of mobile phone tower while the nests of other two species were present at the height of $13 \mathrm{~m}$. The design of this tower also has the zig zag arrangement (Fig.1(a)). On transmission lines, 99\% of the nests were made by only one species, i.e. Black kite. It is observed that a statistically significant association is present between tower design and a presence of nests on them (test-G_ 189.1, 3df, PB 0.01). Thus, the tallest tower type (a) is more used by Black kites whereas the smaller although similar in design, type $\mathrm{c}$, is selected by other avian species including House crow, Common myna, Eurasian collard dove. Black kite does not found to be making nests on electricity towers.

\section{Nests distribution in zones in relation to habitat}

The zones 7 to 11 (mostly southwestern side) recorded the highest number of nests on all types of power structures, i.e. electricity towers, mobile phone towers and transmission lines. The $92 \%$ of nests found on electricity towers were present in these zones. Similarly, $60 \%$ of all nests present on the mobile phone towers were also present in these zones. The zone 9 was the richest in number of nests. All of the nests $(100 \%)$ present on transmission lines were present in zones 7 to 11 .

\section{Discussion}

The use of power lines for roosting and nesting by different avian species has been reported in many areas of the world $[4,20$, 21]. House crow, Black kite, Common myna and House sparrow are the most frequent species roosting on these structures (Fig. 2). The reason for the abundance of House crow and Common myna and House sparrow may be their overall higher population among the avian specie in the area. Noreen and Sultan [22] reported that House crow and Common myna and House sparrow are the most abundant species present in the study area. House sparrow is an urbanized bird [20, 23] and inhabited to live in the cities with human settlements and so it is common for it to use the power structures as roosting sites. The fourth dominant species is Black kite using these structures as roosting and nesting site extensively. Many raptors have also been reported to use these electricity structures for roosting and nesting in other regions of the world $[4,24]$ but Black kite has not been reported earlier. The number of Rock dove roosting on these wires is also high as these domestic pigeons use wires in between the flights and departures to home when people flew them routinely for game purposes. The other air born species (swifts, martins and swallows) were also present on the wires because they remain flying most of times [25] and may be use wires as roosting sites. 


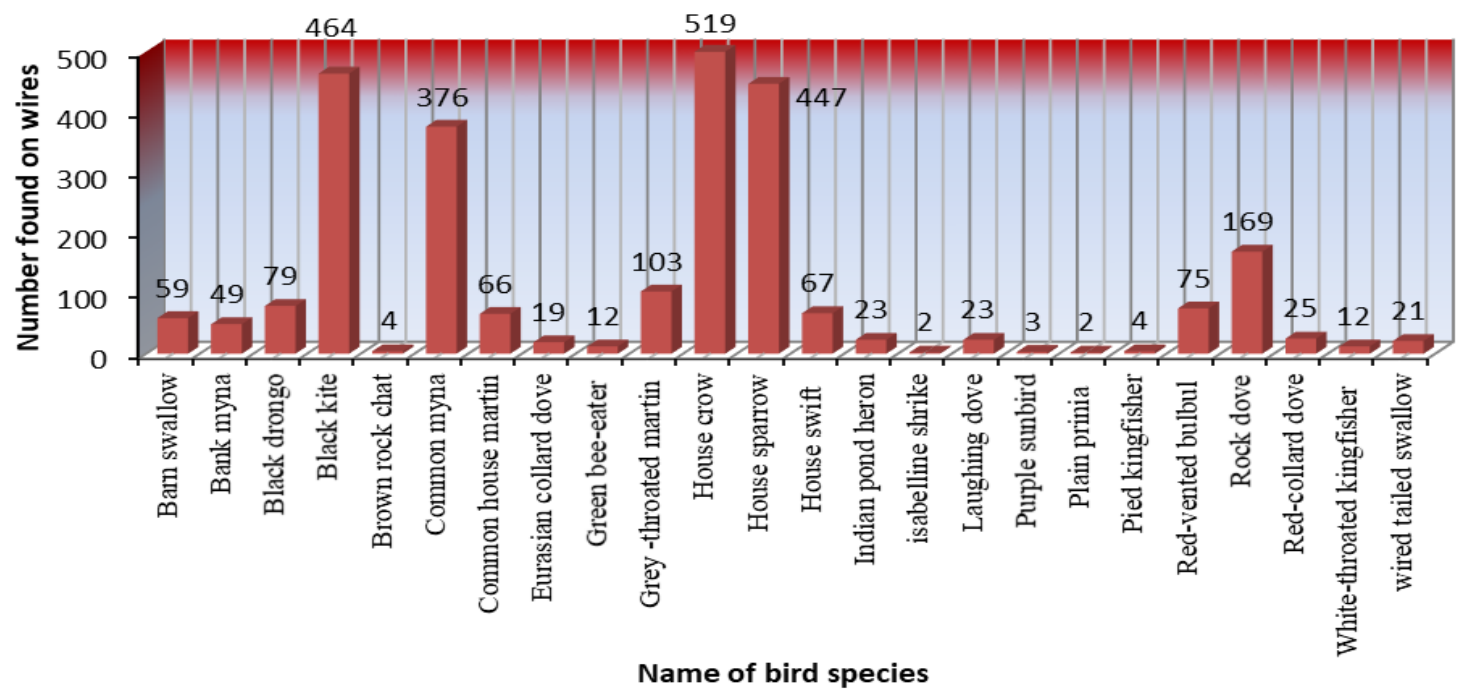

Figure 2. Total number of avian species found on the power structures (electricity towers, mobile phone towers, wires and transmission lines)

From the 16 recorded avian families (Fig. 3), 6 families such as Corvidae, Accipitridae, Passeridae, Sturnidae, Hirundinidae, and Columbidae made $89 \%$ of birds' population sitting on wires and towers. The possible reason may be the abundance of in the region [22] and the air born nature of other families (e.g., Hirundinidae) which use these structures extensively between the flights.

The birds' distribution in different zones of the city showed that zone 2 and 6 , located in northeastern part, are the richest in abundance and diversity (Fig. 4(a,b)). The most likely reason is the presence of Canal Bank forests close to the zone 2. This entire zone consists of canal bank forest having a mixed tree plantation with dominant species of Eucalyptus, Ficus, Semal and Mesquit which is 3 to 4 meters wide and forms a about $5 \mathrm{~km}$ in length around the city area [22]. These trees are providing the essential habitat to birds hence turning into an avian diversity hot spot when there is a widespread deforesting in the region. Second region where birds are concentrated is a temporary waste dump present along the GT road serving as a food source for there are leftover kitchen items in city solid waste [22]. Birds are congregated for foraging on the areas where waste dumps are present [26]. The lowest number of birds is present in the zones 13 and14 located in the western side of the city. The reason is the presence of urbanized area with less number of trees on this side of the city. The distribution pattern of some interesting species on powers structures in different zones of the city is shown in (Fig. 4). Spatial variation of House sparrow population showed that this species is distributed fairly evenly in all zones of the city but more concentrated in zone 2 and 6 . These zones are located close to the Canal Bank forest (Zone 2) and the active waste dump site (Zone 6). Spatial distribution of Black kite shows that it is also present in significant number in the zones 7 to 9 in addition to its abundance in zones 2 and 6 . The close vicinity of Upper Chenab canal in the zones 7 to 9 where there is an availability of fish in canal and vantage points from mobile phone towers and transmission lines passing over the canal. The (Fig. 4(d) is showing that the population of Laughing dove is dispersed more or less evenly in the 
city and is always found to be found present in each zone sitting on wires. The spatial distribution of Barn swallows (Fig. 4(f)) showed that it is also concentrated on the canal bank forest area and the landfill site but can also be found in other areas of city.

The most interesting trend emerged is the distribution of nests on towers in different zones as compared to the population distribution of birds in these zones. The abundance of birds is more on the eastern side of the city but the nests on towers are concentrated on the western side of city. This apparent contradiction can be explained by absences of large size trees in the western side of the city. Most of the area in the western side of city is agricultural land where massive cutting of trees has been carried out in the past resulting in habitat loss. The chain of transmission line and mobile phone towers is present along the agricultural fields where most of nests are present. Therefore, it is hypothesized that the deforestation drove these Raptors to shift their habitat and nesting places from the trees to the man made huge structures. These towers are permanent structures and their place, composition and design does not change from year to year so these avian species are adapting to ecological niche from trees to towers finding these structures as a safe and faraway place from human and other predators access. However, in the eastern side of city the trees are present in better proportion as part of $5 \mathrm{~km}$ canal bank forest attracting birds in large numbers. The low occupation rate $(1.8 \%)$ of the electricity towers for nesting than the transmission lines (32\%) and mobile phone towers $(61 \%)$ is most probably due to the nature of design and material of electricity towers. The construction of electricity towers from concrete and plain design i.e. absence of place of support for the nesting making them less suitable for nesting. The only one type of electricity tower having design similar to the mobile phone tower is preferred for the nesting. The opposite is true for the mobile phone towers and transmission lines. Their design and presence of support seem to make them very suitable for nesting. Infante and Peris [3] also reported that the design of towers of certain types is most suitable and extensively used for the nesting by different avian species. The height of mobile phone towers and transmission lines is also important because the towers with more height are more preferred by birds as compared to small towers [3] so more nests are present on these towers as compared to electricity towers having low height and vice versa.

The nesting preference of avian species (Fig. 4) showed that Black kite is the most common species making nests on the huge mobile phone towers (79\% of all nests) and transmission line (99\% of all nests) to make nests. The use of power lines by raptors have been reported in many areas of the world [3, 4] but the use of mobile phone towers is the first time being reported here. Moreover, Black kite is a species that has not been reported earlier in terms of nesting preference in urban habitat. The frequency of use of power lines by Black kite in Gujranwala is far greater than other raptors in the other parts of the world. In Spain, use of power lines by raptors is only $4.9 \%$ but in the study area it is $79 \%$. Moreover, the interesting finding is that no any other raptor species except Black kite is recorded to be making nests on these structures which are very strange. It can be a symbol that this raptor species has adapted most successfully to the change in urban structures than any other species and its significant population in the city may be a sign of its ecological success in the region. In future may be this species increase in population than any other raptor species by exploiting human structures for nesting and food. The Corvids (i.e. House crow) like to make nests on the electricity towers far more than mobile phone towers. The reason is the 
difference in height as electricity towers are lower in height than the mobile phone towers. This finding is in agreement with the work reported by Infante and Peris [3] that raptors and storks use higher power lines but corvids use lower height power lines. Moreover, every geographic region of the world has its own characteristics of avian species using electricity structures as nesting site, i.e. raptors [27], corvids [3, 27], storks [3] and vultures [4]. Black kite, House crow, Common myna and Laughing dove's nesting behavior have not been reported earlier (Fig. 5).

Principal Component Analysis (PCA) also indicated the group behavior of various species present in the city on the towers, transmission lines and wires. The two major clusters are observed. The first cluster is dominated with abundance and diversity at the eastern side of city where canal bank forest is attracting birds as a suitable habitat by making this part a biodiversity hotspot in the city. The second cluster is present on the opposite side where a cluster of nests making species is over power structures (poles, towers and transmission lines) indicating habitat shift from tree to towers. The main reason is the absence of trees due to which the structures are being preferred for nesting. However, some of the species are showing anomalous behavior though, for instance, Rock dove is among the cluster of towers meaning it has close association with power wires. Some other species like Pied kingfisher, Isabelline shrike, and Purple sunbird, White-throated Kingfisher and Green bee-eaters are not making clusters because these are rare species and one or two birds are recorded during the whole study period (Fig. 6).

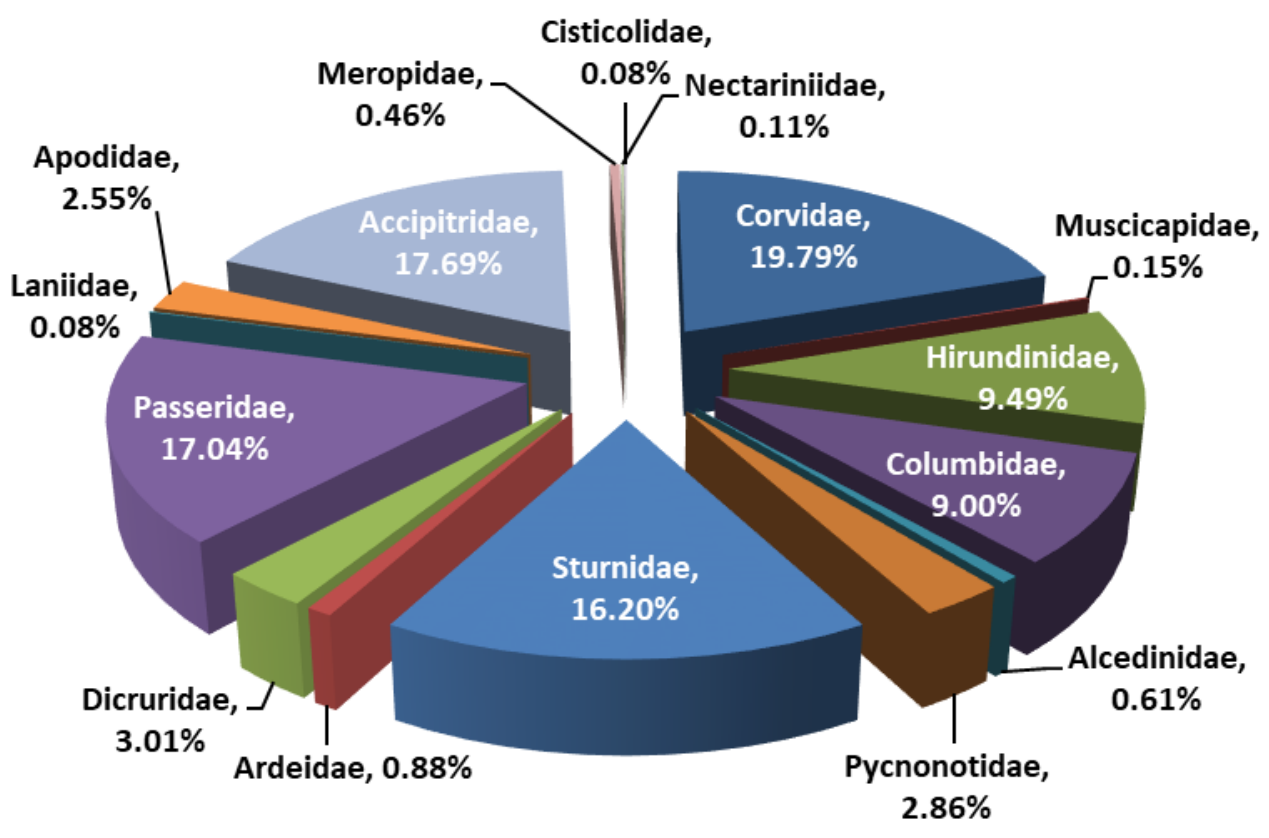

Figure 3. Pie chart showing the percentage of avian families found on power structures 


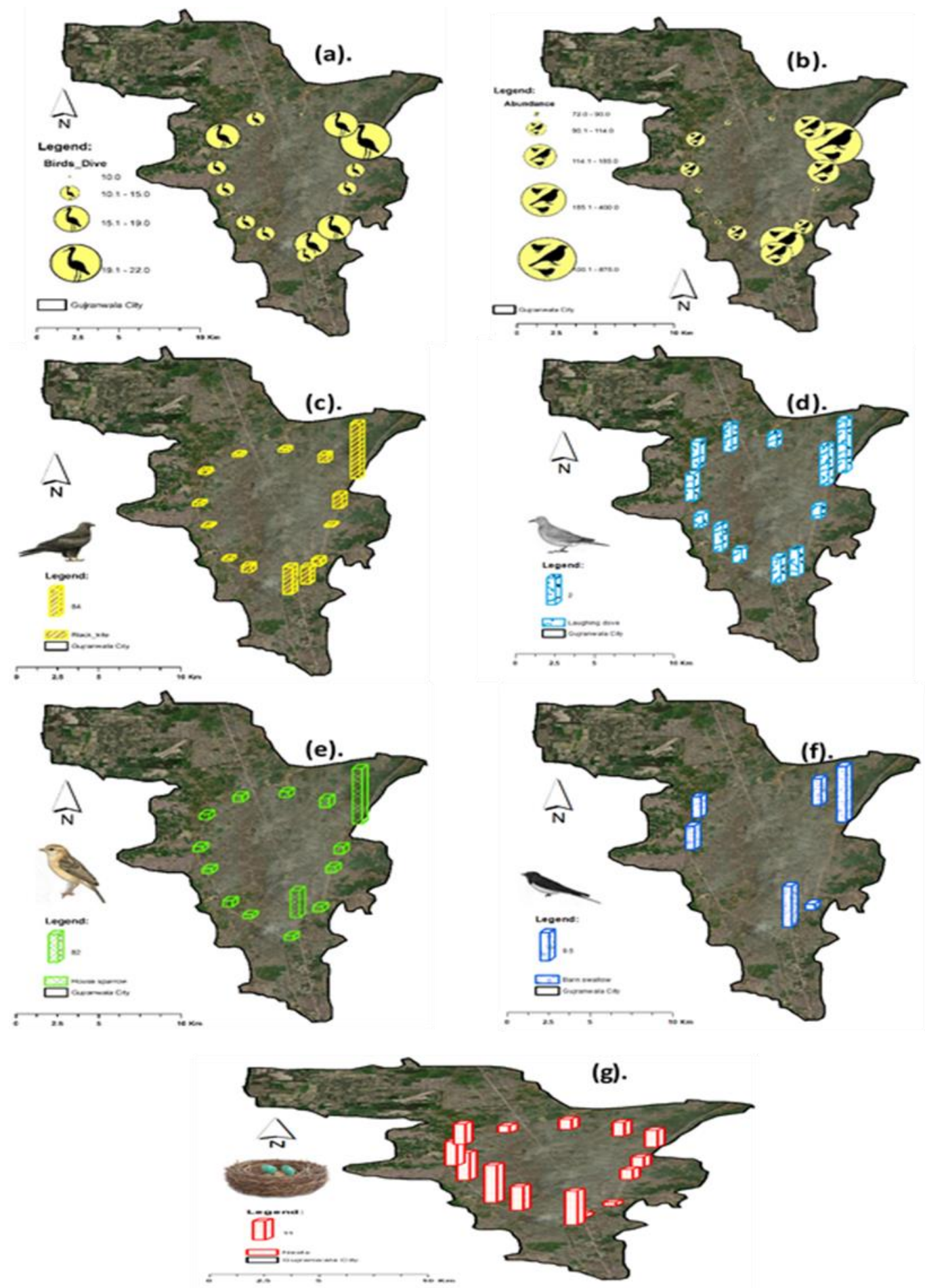

Figure 4. Spatial distribution maps (a-g) of diversity, abundance and selected species of urban avifauna of the study area 

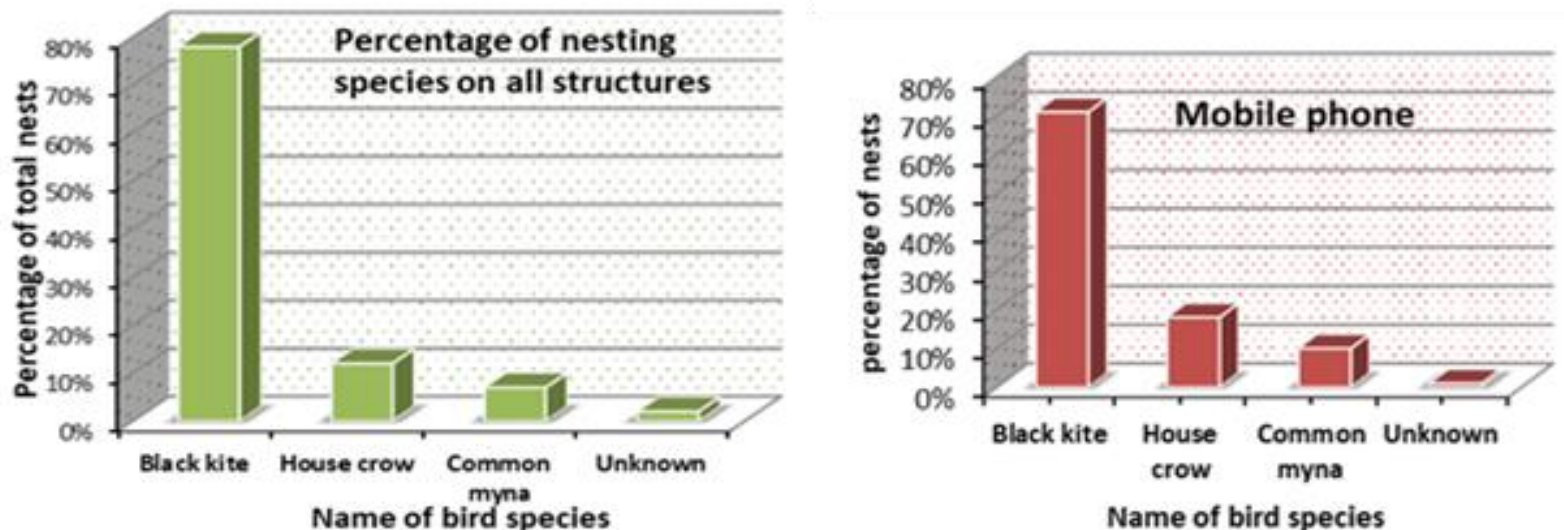

Name of bird species
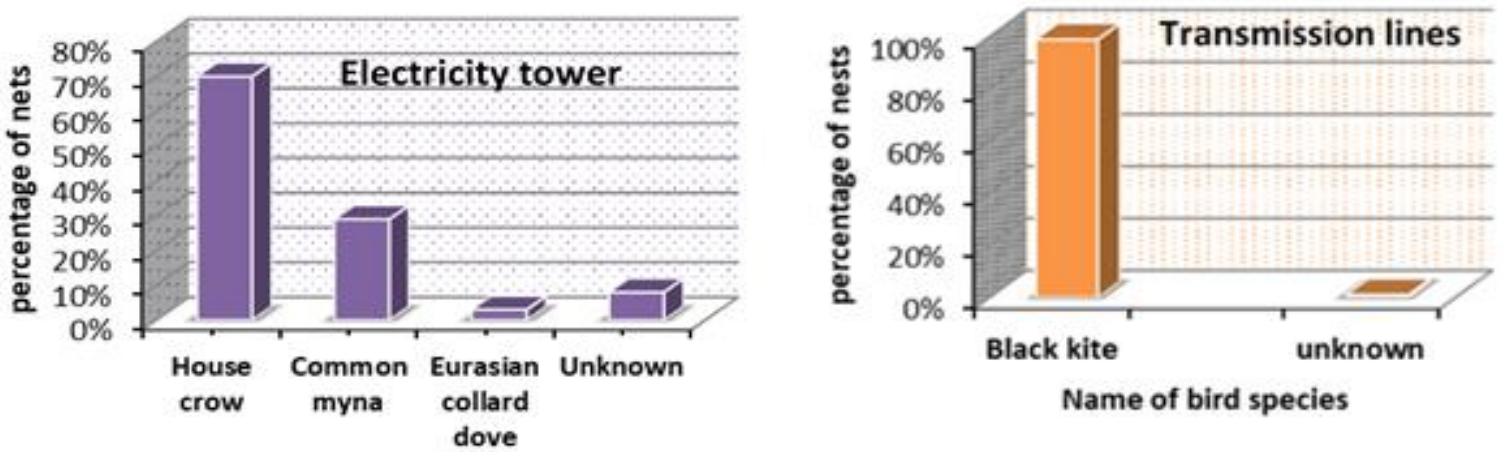

Nmae of bird species

Figure 5. The percentage of avian species using the electricity structures as nesting site

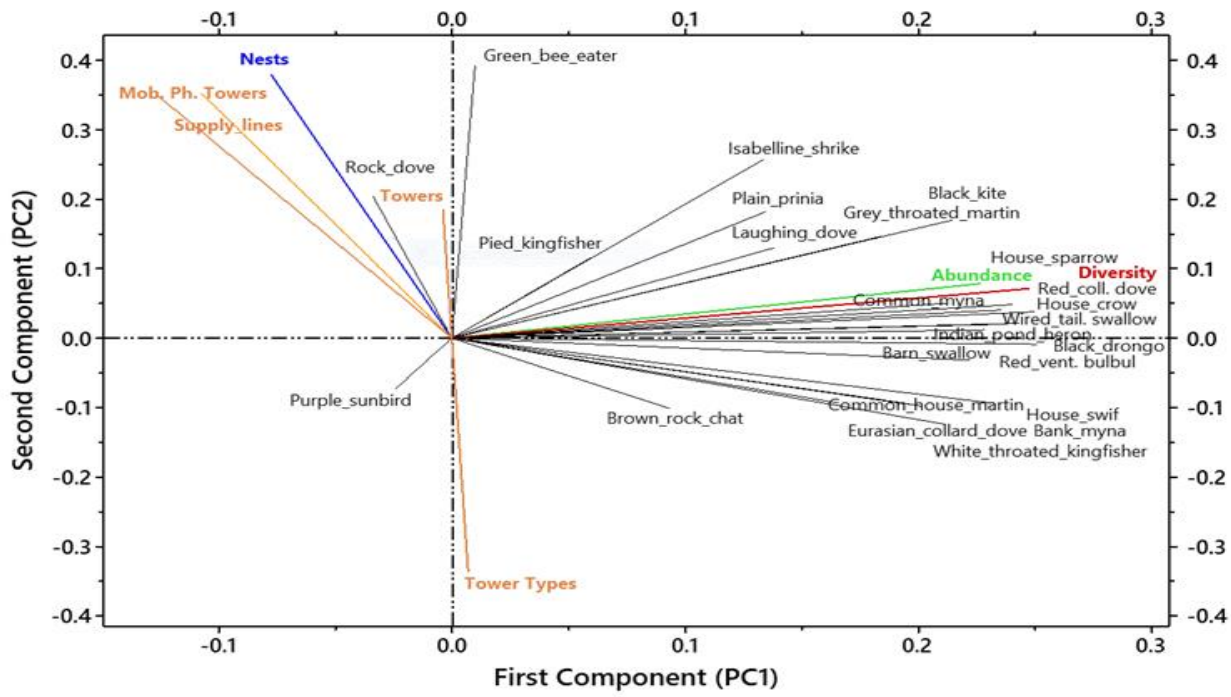

Figure 6. PCA showing the cluster behavior among avian species

\section{Conclusion}

It is concluded from the study that the use of power structures is significantly high by the avian species in terms of abundance and diversity in the city where there is diminished habitat quality like trees. Artificial food 
resources (landfill) attract large bird population hence affecting the spatial distribution patterns of urban avifauna. The dense populated and urbanized areas showed the lowest avian diversity and abundance. The highest occupation rate of mobile phone towers proved that it is the most preferred structure (design and material) for nesting of birds. Black kite and House crow are the most common species using these structures as nesting places. The opposite trend of higher number of nests in areas with low abundance of birds in city showed that the power structures and mobile phone towers are replacing the natural habitats. This shows that these avian species are shifting their habitats trees to the power lines which are being used by local avifauna, as an alternative habitat due to cutting down of tall trees in the urban areas. Height and design of towers also played an important role in terms of choice of nesting and roosting preferences. It is recommended that surrounding forests and urban trees are necessary in order to spatially distribute the avifauna in the area and there is a need plant more trees in the western side of city either in the strip or cluster forms.

A background or baseline situation of birds' population and diversity has to be known first to analyze the impact of lockdowns in the city. Moreover, study conducted during the pandemic restrictions may tell us whether this shift is due to COVID-19 lockdowns or a permanent shift by birds in relation to habitat loss.

\section{Authors' contributions}

Conceived and designed the experiments: $\mathrm{Z}$ Noreen \& K Sultan, Performed the experiments: $Z$ Noreen, Analyzed the data: $Z$ Noreen, Contributed materials/ analysis/ tools: Z Noreen \& K Sultan, Wrote the paper: Z Noreen \& K Sultan.

\section{Acknowledgement}

We are immensely thankful to Mr. Khushi Muhammad and Mr. Imran Raza for their assistance with the fieldwork. We are also immensely grateful to Mr. Muhammad Irfan and Mr. Khubaib Hasan who provided us the vital instruments and co-operation for completion of this work.

\section{References}

1. Mainwaring MC (2015). The use of manmade structures as nesting sites by birds: A review of the costs and benefits. $J$ Nat Conserv 25: 17-22.

2. Morelli F, Beim M, Jerzak L, Jones D \& Tryjanowski P (2014). Can roads, railways and related structures have positive effects on birds. A review. Transp Res D Transp Environ 30: 21-31.

3. Infante O \& Peris S (2003). Bird nesting on electric power supports in northwestern Spain. Ecol Eng 20(4): 321-326.

4. Anderson MD \& Hohne P (2007). African White-backed Vultures nesting on electricity pylons in the Kimberley area, Northern Cape and Free State provinces, South Africa. Vulture News 57: 45-50.

5. Jenkins AR, Smallie JJ \& Diamond M (2010). Avian collisions with power lines: a global review of causes and mitigation with a South African perspective. Bird Conserv Int 20(3): 263278.

6. Bevanger K (1994). Bird interactions with utility structures: Collision and electrocution, causes and mitigating measures. IBIS 136: 412-425.

7. Benitez-Lopez A, Alkemade $\mathrm{R} \&$ Verweij PA (2010). The impacts of roads and other infrastructure on mammal and bird populations: a meta-analysis. Biol Conserv 143(6): 1307-1316.

8. Burgio K R, Rubega MA \& Sustaita D (2014). Nest-building behavior of Monk Parakeets and insights into potential mechanisms for reducing damage to utility poles. Peer J 2:e601. 
9. Maricato L, Faria R, Madeira V, Carreira P \& De Almeida AT (2016). White stork risk mitigation in high voltage electric distribution networks. Ecol Eng 91: 212220.

10. Jabeen N, Farwa U \& Jadoon M (2017). Urbanization in Pakistan: a governance perspective. J Res Soc Pak 54(1): 127136.

11. PBS (2018). Pakistan Bureau of Statistics. Block Wise Provisional Summary Results of $6^{\text {th }}$ Population and Housing Census-2017, Islamabad, Pakistan.

12. Koppen W (1936). Das geographisca system der klimate. In: Handbuch derlimatologie (eds. W Köppen and GC Geiger). Gebr, Borntraeger. pp. 1-44.

13. Sarfaraz S, Arsalan $\mathrm{MH} \&$ Fatima $H$ (2014). Regionalizing the climate of Pakistan using Köppen classification system. Pak Geogr Rev 69: 111-132.

14. Grimmett R, Inskipp $\mathrm{C} \&$ Inskipp $\mathrm{T}$ (1999). Birds of the Indian subcontinent. New Delhi, India: Oxford University Press.

15. Ali S \& Ripley SD (1978). Handbook of the Birds of India and Pakistan together with those of Bangladesh, Nepal, Bhutan and Sri Lanka, 2nd ed. Oxford University Press, Delhi, pp. 226-230.

16. Fowler J, Cohen L \& Jarvis P (1998). Practical Statistics for Field Biology, 2nd Edition. Wiley Publisher, Leicester, UK.

17. Shannon CE \& Weaver W (1963). The mathematical theory of communication. Urbana, I. L: University of Illinois Press. pp. 31-35.

18. Margalef R (1951). Diversidad de especies en lascomunidalesnaturales. Publ Inst Biol Appl 9: 5-27.

19. Pielou EC (1966). The measurement of diversity in different types of biological collections. J Theoret Biol 13: 131-144.
20. Shaw LM, Chamberlain D \& Evans M (2008). The House Sparrow Passer domesticus in urban areas: reviewing a possible link between post-decline distribution and human socioeconomic status. J Ornithol 149: 293-299.

21. Chevallier C, Hernández-Matías A, Real J, Vincent-Martin N, Ravayrol A \& Besnard, A. (2015). Retrofitting of power lines effectively reduces mortality by electrocution in large birds: An example with the endangered Bonelli's eagle. $J$ App Ecol 52: 1465-1473.

22. Noreen Z \& Sultan K (2021). A global modification in avifaunal behavior by use of waste disposal sites (waste dumps/rubbish dumps): a review paper. Pure Appl Biol 10(3): 603-616.

23. Robinson RA, Siriwardena GM \& Crick HQ (2005). Size and trends of the house sparrow Passer domesticus population in Great Britain. IBIS 147: 552-562.

24. Arkumarev V, Dobrev V, Abebe, YD, Popgeorgiev G \& Nikolov SC (2014). Congregations of wintering Egyptian vultures Neophron percnopterus in Afar, Ethiopia: Present status and implications for conservation. Ostrich 85: 139-145.

25. Arena S, Battisti C \& Carpaneto GM (2011). The ecological importance of wetlands for aerial insectivores (swifts, martins and swallows) along the Tyrrhenian coast. Rend Lincei-Sci Fis 22: 395-402.

26. Plaza PI \& Lambertucci SA (2017). How are garbage dumps impacting vertebrate demography, health, and conservation? Glob. Ecol Conserv 12: 9-20.

27. Dixon A, Purev-Ochir G, Galtbalt B \& Batbayar N (2013). The use of power lines by breeding raptors and corvids in Mongolia: Nest-site characteristics and management using artificial nests. $J$ Raptor Res 47: 282-291. 